I E. R. B. Graham et A. Gottschalk, Biochim. Biophys. Acta, 38 (I960) 5 I3.

2 S. Harbon, G. Herman, B. Rossignol, P. Jollès et H. Clauser, Biochem. Biophys. Res. Commun., I7 (1964) 57 .

3 R. Carubelit, V. P. Bhavanandan et A. Gottschalk, Biochim. Biophys. Acta, Ioi (1965) 67.

4 L. A. Elson ET W. T. J. MORGaN, Biochem. J., 27 (1933) 1824.

5 J. L. Reissig, J. L. Strominger he L. F. Leloir, J. Biol. Chem., 2 I7 (1955) 959.

6 F. Maley et G. F. Maley, Biochim. Biophys. Acta, 3 I (1959) 577.

7 S. Roseman, Proc. 6th Intern. Congr. Biochem., New York, 1964, Abstr. vol. VI, p. 467 .

Reçu le 28 décembre, I 965

Biochim. Biophys. Acta, II 7 (1966) 269-272

BBA 2 III27

\title{
Enzymic release of carbon atom 8 from guanosine triphosphate, an early reaction in the conversion of purines to pteridines
}

Previous reports from this laboratory ${ }^{1,2}$ have dealt with the metabolic transformation of purines to the azapteridine antibiotic, toxoflavin, in intact cells of Pseudomonas cocovenenans ${ }^{3}$. In concurrence with data on pteridine biosynthesis from purines in a variety of other biological systems (summarized by Goodwin ${ }^{4}$, and BRown AND REYNOLDS ${ }^{5}$ ), we have shown that, with the exception of C-8, all carbon atoms of the purine ring are directly retained during toxoflavin synthesis. Extension of these studies to cell-free extracts ${ }^{6}$ first provided evidence that an early step in the biosynthetic sequence between purines and toxoflavin consists of the enzymic labilization of C-8 in GTP and its expulsion ultimately as formate. In view of experimental observations, quite similar in nature to these, on the enzymic removal of C-8 from guanine nucleotides in Lactobacillus plantarum ${ }^{7}$ and in Escherichia coli ${ }^{8}$, as well as studies with Salmonella typhimurium extracts ${ }^{9}$ that bear on the same problem, further documentation and extension of our preliminary findings was deemed advisable.

The ability of crude, cell-free extracts of $P$. cocovenenans to catalyze the formation of ${ }^{14} \mathrm{CO}_{2}{ }^{*}$ from $5^{\prime}$-phosphoribosyl derivatives of $\left[8^{14} \mathrm{C}\right]$ guanine or xanthine was chosen initially as a measure of purine metabolic activity directed toward intermediates in toxoflavin biosynthesis. When the system was incubated at $\mathrm{pH}$ 9-Io and further supplemented with both ATP and $\mathrm{Mg}^{2+}$ such an enzymic reaction did indeed take place. $\mathrm{C}-8$ of the purine nucleus apparently was the only atom expelled as $\mathrm{CO}_{2}$ under these conditions, since (a) C-2 or C-6 labeled guanines did not yield ${ }^{14} \mathrm{CO}_{2}$, and (b) uniformly ${ }^{14} \mathrm{C}$-labeled GMP formed only $10 \%$ as much ${ }^{14} \mathrm{CO}_{2}$ as did an equal amount of $\left[8-{ }^{14} \mathrm{C}\right] \mathrm{GMM}$. As purification of the enzymic components of the extract was undertaken, it became clear from several considerations that a carbon atom at the oxidation level of formate was actually the initial product of C-8 release. Subsequently, assays were carried out routinely by treating incubated samples for $2.5 \mathrm{~min}$ at $95^{\circ}$ with $\mathrm{I} .0 \mathrm{ml}$ of $0.67 \mathrm{M} \mathrm{HgSO}_{4}$ dissolved in $2.7 \mathrm{~N} \mathrm{H}_{2} \mathrm{SO}_{4}{ }^{\star \star}$. Working within at $25^{\circ}$.

* Determined as radioactivity absorbed in alkali on being rendered volatile by $1 \mathrm{~N}_{2} \mathrm{SO}_{4}$

* Under these conditions, formate and substances containing acid-labile formyl groups are quantitatively oxidized to ${ }^{14} \mathrm{CO}_{2}$. Of a large number of labeled purine derivatives and related compounds tested, only $\left[{ }^{14} \mathrm{C}\right]$ urea and $\left[8-{ }^{14} \mathrm{C}\right]$ uric acid were cleaved significantly to ${ }^{14} \mathrm{CO}_{2}$ by this procedure. Urea was ruled out as a product of purine breakdown in crude extracts by separate studies using urease in place of $\mathrm{Hg}^{2+}$ oxidation. The formation of uric acid from purines could not be disproved until purification of the system had resulted in complete loss (as measured by $\mathrm{Hg}^{2+}$ oxidation) of the ability of $\left[8-{ }^{14} \mathrm{C}\right]$ guanine or xanthine to serve as substrates for release of $\mathrm{C}-8$. 
the specific limitations of various kinetic parameters of the system, we have achieved approximately 30 -fold purification of the soluble enzyme(s) by conventional means involving the use of hydroxylapatite, $\left(\mathrm{NH}_{4}\right)_{2} \mathrm{SO}_{4}$ precipitation, column chromatography on Sephadex G-200, and calcium phosphate gel. In the absence of ATP and $\mathrm{Mg}^{2+}$ only GTP serves as a substrate for the release of purine C-8 (Fig. I), while all other guanine or xanthine derivatives tested are completely ineffective in this capacity. A further requirement for divalent cations $\left(\mathrm{Mg}^{2+}\right.$ was by far the most effective) could be shown following pretreatment of the enzyme preparations with versene and subsequent removal of the chelating agent by dialysis. No other cofactor requirements have thus far been detected. AMP, an inhibitor of 2-amino-4-hydroxy-6-hydroxymethylpteridine synthesis from GTP in S. typhimurium ${ }^{9}$, has not been observed to cause significant inhibition of the reaction.

Enzyme preparations at the present stage of purification possessed low but measurable phosphohydrolase activity which partially converted added GTP to GDP under the conditions of incubation for C-8 release. Since GTP was employed at a level insufficient to function both as an energy source equivalent to ATP as well as a precursor of GDP (Fig. I) it is extremely improbable that the triphosphate must first be split to the diphosphate before ring-cleavage at $\mathrm{C}-8$ takes place. Furthermore, since yields of formate (or formyl residues) equivalent to well over half of the added GTP could be obtained under optimal reaction conditions in other experiments, an intermolecular mechanism for imidazole ring rupture, requiring utilization of the pyrophosphate bond energy of one or more molecules of GTP for C-8 expulsion from an additional molecule of substrate, is not possible.

As shown in Table I, loss of C-8 was accompanied by an equivalent loss of the guanine moiety of GTP. In a separate experiment, ${ }^{14} \mathrm{C}$-labeled pteridines could

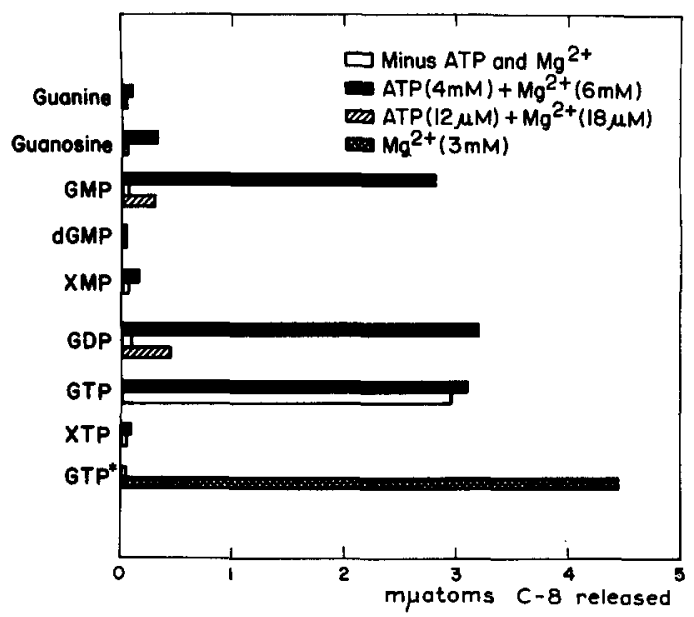

Fig. I. Effect of ATP and $\mathrm{Mg}^{2+}$ on enzymic release of C-8 from a variety of guanine and xanthine derivatives. Shortened Thunberg tubes were incubated for $I \mathrm{~h}$ at $43^{\circ}$ with $9 \mathrm{~m} \mu$ moles of the indicated $\left[8{ }^{14} \mathrm{C}\right]$-labeled substrate, (specific activity, $8.3 \cdot 10^{5}$ counts $/ \mathrm{min}$ per $\mu \mathrm{mole}$ ) and $\mathrm{o}$. I $5 \mathrm{mg}$ protein (LowRy et al. ${ }^{10}$ ) from the eluate of a Sephadex G-20o column, in the presence of $0.2_{2} \mathbf{M}$ diethanolamine buffer ( $\mathrm{pH} 9.6$ ). Volume, $0.45 \mathrm{ml}$. For versene treatment, tlie enzyme preparation was incubated $2 \mathrm{~min}$ at $37^{\circ}$ with $0.025 \mathrm{M}$ versene at $\mathrm{pH} 6.8$, and then dialyzed $2 \mathrm{~h}$ against several changes of $0.005 \mathrm{M}$ Tris buffer ( $\mathrm{pH} 7.0$ ). Release of $\mathrm{C}-8$ was assayed by $\mathrm{Hg}^{2+}$ oxidation method, as described in the text. *, Incubations performed with versene-treated, dialyzed enzyme. 
be demonstrated as products after treatment of incubation mixtures with glyoxal in the presence of carrier amounts of either 4,5-diamino uracil or 2,4,5-triamino6-hydroxypyrimidine. The total quantity of labeled pteridines formed was in very good agreement with the extent of C-8 labilization. Lumazine, however, contained more than Io times as much ${ }^{14} \mathrm{C}$ than 2 -amino-4-hydroxypteridine, showing that an extensive enzymic deamination of the 2-amino group of GTP had occurred. Inasmuch as XTP is improbable as an intermediate in the release of C-8 (Fig. I) these data suggest that, during the biosynthesis of toxoflavin, deamination at $\mathrm{C}-2$ follows closely upon imidazole ring rupture of GTP.

The loss of C- 8 as formate probably occurs through more than just a single chemical event. Preliminary results obtained using a charcoal adsorption assay technique indicate that approximately four-fifths of the GTP ring-cleavage products

\section{TABLE I}

STOICHIOMETRIC RELATIONS OF C-8 RELEASE TO LOSS OF GUANINE MOIETY AND FORMATION OF 4,5-DIAMINO PYRIMIDINES

In each experiment, $5^{\mathrm{I}} \mathrm{m} \mu$ moles of uniformly ${ }^{14} \mathrm{C}$-labeled GTP $\left(3.4 \cdot \mathrm{IO}^{6}\right.$ counts $/ \mathrm{min}$ per $\left.\mu \mathrm{mole}\right)$ were incubated as before with either an $\left(\mathrm{NH}_{4}\right)_{2} \mathrm{SO}_{4}$ fraction (I) or a Sephadex G-2oo fraction (II). Unincubated samples and those lacking enzyme were also carried through the entire procedure. Aliquots were removed after $\mathrm{I} h$ for determination of $\mathrm{C}-8$ release. In $\mathrm{I}$, the samples were hydrolyzed in $0.2 \mathrm{~N} \mathrm{HCl}$ at $100^{\circ}$ for $30 \mathrm{~min}$, and then treated with charcoal. After thorough washing, the charcoal was eluted several times with ethanolic ammonia; the combined eluates were evaporated and chromatographed (descending) on Whatman No. 3 paper in isopropanol-6 $\mathrm{N} \mathrm{HCl}(67: 33, \mathrm{v} / \mathrm{v})$. The guanine areas were located under ultraviolet light (as well as by ${ }^{14} \mathrm{C}$ scanning), eluted with dilute $\mathrm{NH}_{4} \mathrm{OH}$ and assayed for ${ }^{14} \mathrm{C}$. In II, separate aliquots were treated with either 2,4,5-triamino6-hydroxypyrimidine or 4,5-diaminouracil (II.5 $\mu$ moles each) and reacted for $30 \mathrm{~min}$ on the steam-bath with glyoxal at $\mathrm{pH} 3 .{ }^{14} \mathrm{C}$-Labeled pteridines were purified by chromatography on alumina ${ }^{11}$, and then to constant specific activity through three successive paper chromatographic steps. Controls with $\left[2{ }^{14} \mathrm{C}\right] 2,4,5$-triamino-6-hydroxypyrimidine showed that the 2 -amino group in this substance was not deaminated as a result of the above chemical manipulations.

\begin{tabular}{|c|c|c|c|c|}
\hline $\begin{array}{l}\text { Expt. } \\
\text { No. }\end{array}$ & $\begin{array}{l}\text { C-8 released } \\
\text { (m } m \text { atoms) }\end{array}$ & $\begin{array}{l}\text { Guanine residues } \\
\text { of GTP destroyed } \\
\text { (mumoles) }\end{array}$ & $\begin{array}{l}2,4,5 \text {-triamino- } \\
\text { 6-hydroxy- } \\
\text { pyrimidine residues } \\
\text { formed (mumoles) }\end{array}$ & $\begin{array}{l}\text { 2,6-dihydroxy- } \\
\text { 4,5-diamino- } \\
\text { pyrimidine residues } \\
\text { formed (mumoles) }\end{array}$ \\
\hline I & I6.6 & $I_{4} \cdot 5$ & 一 & - \\
\hline II & 6.6 & - & 0.5 & 6.5 \\
\hline
\end{tabular}

containing C-8 constitute free formate, while the remainder may represent 5- or 6formarnidopyrimidine derivatives. Further work will be necessary in order to evaluate separately the two processes presumably concerned, i.e. imidazole ring scission and removal of the formyl group, and to clarify the sequence of events and mechanism of this early reaction in the enzymic conversion of GTP to toxoflavin and other pteridine derivatives.

This investigation was supported by U.S. Public Health Service Grants GMI0359 and GM-I3325. One of the authors (B.L.) holds a Career Development Award (GM-3II5-K-3) from the National Institutes of Health.

Department of Biological Chemistry,

BRUCE LEVENBERG

The University of Michigan,

DORIS K. KACZMAREK

Ann Arbor, Mich. (U.S.A.) 
I B. Levenberg ANd S. N. Linton, Federation Proc., 22 (1963) 592.

2 B. Levenberg and S. N. Linton, J. Biol. Chem., 24 I (1966) 846.

3 P. A. Van Damme, A. G. Johannes, H. C. Cox and W. Berends, Rec. Trav. Chim., 79 (Ig6o) 255 .

4 T. W. Goodwin, The Biosynthesis of Vitamins and Related Compounds, Academic Press, New York, I963, Pp. 4I-5I and I05-III.

5 G. M. Brown and J. J. Reynolds, Ann. Rev. Biochem., 32 (I963) 4 Ig.

6 B. Levenberg, Federation Proc., 24 (1965) 669.

7 T. Shiota and M. P. Palumbo, J. Biol. Chem., 240 (1965) 4449.

8 A. W. Burg and G. M. Brown, Biochim. Biophys. Acta, I I 7 (I966) 275.

9 F. R. Dalal and J. S. Gots, Biochem. Biophys. Res. Commun., 20 (I965) 509.

io O. H. Lowry, N. J. Rosebrough, A. L. Farr and R. J. Randall, J. Biol. Chem., I93 (195I) 265 .

i i A. Albert, D. J. Brown and G. Chemseman, J. Chem. Soc., (I95I) 474.

Received December 28th, I965

Biochim. Biophys. Acta, II 7 (I966) 272-275

BBA 2 I I28

\section{The biosynthesis of folic acid}

\section{Enzymatic conversion of carbon atom 8 of guanosine triphosphate to formic acid}

Previous investigations have established that purines can be converted to pteridines by whole organisms ${ }^{1-3}$ as well as by cell-free enzyme preparations ${ }^{4-6}$. REYNOLDS AND BROWN ${ }^{4,5}$ found that guanine compounds are the specific purines utilized for pteridine formation by extracts of Escherichia coli and that during these enzymatic transformations carbon atom 8 of guanine is not incorporated into the pteridine product, determined as enzymatically-formed dihydrofolic acid. The latter finding is in agreement with the results of VIEIRA AND SHAW ${ }^{3}$ who showed that, during the production of pteridines from purines by whole organisms, C-8 of the purine does not appear in the pteridine product. These facts have led to the proposal ${ }^{5}$ that an early step in folic acid biosynthesis involves the enzymatic cleavage of the imidazole ring portion of a guanine nucleotide with the removal of C-8 of guanine. The present communication describes some recent experiments designed to obtain information about the nature of the enzyme or enzymes responsible for this phenomenon and the identity of the products formed. Similar reactions have recently been shown to be catalyzed by enzyme systems from Pseudomonas cocovenenans ${ }^{7,8}$ (responsible for the formation of toxoflavin from guanosine triphosphate) and from Lactobacillus plantarum $^{6}$ in the conversion of guanine nucleotides to folic acid compounds.

Initial observations indicated that crude extracts of $E$. coli (prepared as described previously $\left.{ }^{9}\right)$ catalyze the removal of $\mathrm{C}-8$ of guanine nucleotides $\left(\left[8-{ }^{14} \mathrm{C}\right]-\right.$ labeled) as $\mathrm{CO}_{2}$. The latter compound was collected as $\mathrm{BaCO}_{3}$. We later found that the crude extract was rich in formic dehydrogenase (EC I.2.2.I), and we then recognized that the $\mathrm{CO}_{2}$ could have been produced from formic acid formed during the cleavage of the guanine nucleotide. In subsequent experiments mercuric acetate was added to incubated reaction mixtures to oxidize completely any formic acid that might be produced.

The enzyme preparation used for most of the work to be described was obtained as follows. Extracts of $E$. coli B were prepared as described previously9. The resulting 